\title{
DETERMINATION OF PAIN IN MUSCULOSKELETAL SYSTEM REPORTED BY OFFICE WORKERS AND THE PAIN RISK FACTORS
}

\section{SEVIM CELIK ${ }^{1}$, KADİR CELİK ${ }^{2}$, ELIF DİRIMESE ${ }^{1}$, NURTEN TASDEMİR ${ }^{1}$, TARIK ARIK ${ }^{3}$, and İBRAHIM BÜYÜKKARA ${ }^{4}$}

${ }^{1}$ Bulent Ecevit University, Zonguldak, Turkey

Health Science Faculty, Department of Nursing

${ }^{2}$ Gökcebey Department of Revenue, Zonguldak, Turkey

${ }^{3}$ American Hospital, Istanbul, Turkey

General Intensive Care Unit

${ }^{4}$ Dokuz Eylul University Hospital, Izmir, Turkey

General Surgery Clinic

\begin{abstract}
Objectives: This research was conducted as a cross-sectional descriptive study aimed at determining the existence of pain in the musculoskeletal system among office workers and the reasons for it. Material and Methods: The sample consisted of 528 office workers. Collection of data was achieved using a questionnaire prepared by the researchers in line with information from the literature. Results: The male and female office workers most frequently complained of pain in the lower back $(55.1 \%)$, neck $(52.5 \%)$ and back (53\%). It was seen that out of the variables relating to the work environment, those which had the most significant effect on muscular-skeletal system pain were sitting at the desk for a long time without a break, working sitting on a chair that supported only the lumbar area and the arms, having the computer mouse at a distance from the keyboard, having the head inclined at $45^{\circ}$ when working, working holding both forearms above the level of the desk, not taking exercise in daily life, and having a moderate or extremely stressful workplace $(\mathrm{p}<0.05)$. Conclusions: The conclusion has been reached in this study that in order for office workers not to suffer musculoskeletal system pain, it is very important that the working environment should be ergonomically arranged and that various measures should be taken to ensure healthy life behavior. Int J Occup Med Environ Health 2018;31(1):91-111
\end{abstract}

Key words:

Pain, Computer users, Ergonomics, Work-related musculoskeletal complaints, Office worker, Work design

Received: January 23, 2016. Accepted: November 9, 2016.

Corresponding author: E. Dirimese, Bulent Ecevit University, Health Science Faculty, Department of Nursing, İbn-i Sina Campus Esenköy Street, 67600 Kozlu, Zonguldak, Turkey (e-mail: elifim67@yahoo.com). 


\section{INTRODUCTION}

In industrially developed nations, disorders of the musculoskeletal system are progressively increasing and are resulting in significant costs. Work-related musculoskeletal disorders are defined as damage to or disease of muscles, nerves, tendons, joints, and cartilage or spinal discs resulting from risk factors in the working environment. Studies have shown that these diseases increase as the average age of the society rises [1].

In Turkey, musculoskeletal disorders (MSDs) are ranked 3rd among disabilities at 9.9\%, and these disorders are accepted legally as work-related diseases. Despite this, employees and employers have insufficient knowledge of the frequency of MSDs, risk factors, insurance payments for lost work, preventive training, and the effectiveness of ergonomic approaches [1-3]. In the case of MSDs, pain is a frequently observed symptom. Pain is a subjective experience, and determining its presence in working life and the factors which cause it is of great importance in taking the necessary corrective measures and in planning early treatment approaches [4,5].

Industrialized countries have recently seen a dramatic increase in the frequency and cost of MSDs; the attention of employees, employers, the government, health care systems and insurance companies has been drawn to this topic, and there has been an increase the number of studies on ergonomic programs and rehabilitation approaches examining risk factors, ergonomics education and ergonomic approaches. Awareness of protection and ergonomics has begun to rise and ergonomic education and ergonomic approaches are beginning to be applied in workplaces [6,7]. It is known that work-related MSDs arise in tendons, muscles, nerves and other soft tissues from damage-causing enforced repeated actions, holding the body in an unsuitable position, a stressful working life, working for long periods without a break, and ergonomic inadequacies $[8,9]$. The early symptoms of MSDs may appear suddenly or they may emerge slowly over a long period. The most important complaint of workers is acutely developing or chronically continuing pain. Other early symptoms are swelling, numbness, rash, weakness or restriction of movement. Early recognition of the symptoms of work-related MSD damage is important for reducing damage which may occur in the early stages and for providing prompt treatment $[10,11]$.

The most important element for effective ergonomics in the prevention of disorders arising in the musculoskeletal system is arranging programs in workplaces. Such a program should include keeping records of work-related illnesses and work accidents, early identification and reporting of symptoms, systematic scanning of workers' health and reporting of the results, implementing protective services such as limitations on work and giving periodic training to workers, ensuring communication between workers on every shift and workplace health teams, and not obstructing workers from reporting problems to health teams [12].

In the light of this information, this study was performed with the aim of determining the existence of and reasons for pain-related to the musculoskeletal system among office workers in the university and government organizations in the provincial capital of Zonguldak, and of providing a guide for training to be conducted on this topic.

\section{MATERIAL AND METHODS \\ Type of study}

The research was conducted as a cross-sectional and descriptive study.

\section{Population and sample of the study}

The population of the study consisted of the 720 office workers employed between February and May 2014 in the offices of the university, National Education Ministry, Social Security Institution, law courts, police, municipality and tax offices of the provincial capital of Zonguldak province, Turkey. 
In determining the research sample, it was intended to reach the whole population by applying the calculation method. The sample was formed from 528 office workers who could speak, understand and write Turkish, had no communication problems, worked at a desk, were not on leave or sick when the research was conducted, and took part voluntarily in the study. The rate of participation in the study was found to be $73.3 \%$.

\section{Collection of data}

Collection of data was achieved using a questionnaire prepared by the researchers in line with information from the literature [13-16]. This questionnaire contained questions on the demographic data of the workers, whether they took exercise, the length of time they stood or sat continuously, the number of breaks they took, whether they performed heavy lifting while working, problems which they faced at work and stress levels, the position of their body, computer and computer mouse, the type of a chair they used, and the existence and characteristics of problems with the musculoskeletal system.

Before starting the study, written permission was obtained from the organizations where it was to be conducted, and informed oral consent was obtained from the participants. Data collection was performed by the researchers during working hours between February and May 2014 by going to the organizations which had been determined. Information was given to the participants concerning the research. The questionnaires were distributed and took approximately 15 min to complete, and were collected back the same day.

\section{Data evaluation}

Data evaluation was performed by the SPSS 18.0 program using such descriptive statistical instruments as numbers, percentages, arithmetic means and standard deviations. Multiple-linear regression analyses were conducted to assess the relationship between the characteristics of female and male office workers and pain complaints. Differences in pain complaints rates of female and male office workers were expressed as odds ratios (OR) and $95 \%$ confidence interval (CI). A statistical significance level of 0.05 was chosen.

\section{RESULTS}

The mean age of the office workers was $38.55 \pm 9.79$ years old; $34.4 \%$ of female and $35.3 \%$ of male were between 32 and 42 years old, majority of them were married; $40.4 \%$ of female and $34.9 \%$ of male worked in the university, and majority of female and male had been working for 1-5 years. It may be seen in the same table that $58.5 \%$ of the female office workers had a normal body mass index while $51.2 \%$ of male were overweight, and that a half of female $(50.7 \%)$ and male $(48.4 \%)$ did not take exercise in their daily lives (Table 1).

The mean time spent continuously standing by the office workers was $1.88 \pm 1.16 \mathrm{~h}$, and the time spent sitting was $4.64 \pm 2.21 \mathrm{~h}(43.7 \%$ of female and $46.9 \%$ of male took 2 or 3 breaks a day). It was found that most of the female and male office workers did not perform any exercise in the workplace, a half of female $(58.1 \%)$ and male $(55.8 \%)$ rarely lifted heavy weights. Furthermore, female and male office workers stated that they experienced difficulties while working and they were not the majority who did not have recurrent hard activity in the workplace and they stated that their work was moderately stressful (Table 1).

It may be seen from the Table 1 that $66.3 \%$ of female and $65.1 \%$ of male workers worked at their desks with their upper backs in a bent position; most of female (72.6\%) and male $(67.8 \%)$ kept both arms above the level of the desk, and one third of female (35.9\%) and $40.3 \%$ of male kept both legs bent. The same table shows that most of the office workers kept their computers directly opposite themselves, and that their computer mouse $(90 \%$ of female, $87.6 \%$ of male) was kept close to the keyboard. 
Table 1. Characteristics of respondents in the study aimed at determining the existence of pain in the musculoskeletal system among office workers

\begin{tabular}{|c|c|c|}
\hline \multirow[t]{2}{*}{ Variable } & \multicolumn{2}{|c|}{$\begin{array}{c}\text { Respondents } \\
(\mathrm{N}=528) \\
{[\mathrm{n}(\%)]}\end{array}$} \\
\hline & $\begin{array}{c}\text { females } \\
(\mathrm{N}=270)\end{array}$ & $\begin{array}{c}\text { males } \\
(\mathrm{N}=258)\end{array}$ \\
\hline \multicolumn{3}{|l|}{ Age $(\mathrm{M} \pm \mathrm{SD}=38.55 \pm 9.79)$} \\
\hline 21-31 years & $79(29.3)$ & $76(29.5)$ \\
\hline $32-42$ years & $93(34.4)$ & $91(35.3)$ \\
\hline $43-53$ years & $83(30.7)$ & $62(24.0)$ \\
\hline$\geq 54$ years & $15(5.6)$ & $29(11.2)$ \\
\hline \multicolumn{3}{|l|}{ Marital status } \\
\hline married & $178(65.9)$ & $196(76.0)$ \\
\hline unmarried & $92(34.1)$ & $62(24.0)$ \\
\hline \multicolumn{3}{|l|}{ Workplace } \\
\hline university & $109(40.4)$ & $90(34.9)$ \\
\hline education ministry & $19(7.0)$ & $28(10.9)$ \\
\hline social security institution & $31(11.5)$ & $9(3.5)$ \\
\hline law court & $30(11.1)$ & $29(11.2)$ \\
\hline police & $16(5.9)$ & $45(17.4)$ \\
\hline municipality & $29(10.7)$ & $31(12.0)$ \\
\hline tax office & $36(13.3)$ & $26(10.1)$ \\
\hline \multicolumn{3}{|l|}{ Work experience } \\
\hline $1-5$ years & $72(26.7)$ & $85(32.9)$ \\
\hline $6-10$ years & $68(25.2)$ & $53(20.5)$ \\
\hline $11-15$ years & $34(12.6)$ & $30(11.6)$ \\
\hline $16-20$ years & $36(13.3)$ & $34(13.2)$ \\
\hline$\geq 21$ years & $60(22.2)$ & $56(21.7)$ \\
\hline \multicolumn{3}{|c|}{ Body mass index $(\mathrm{BMI})(\mathrm{M} \pm \mathrm{SD}=25.44 \pm 3.85)$} \\
\hline underweight (0-18.4) & $5(1.9)$ & $2(0.8)$ \\
\hline normal (18.5-24.9) & $158(58.5)$ & $85(32.9)$ \\
\hline overweight (25-29.9) & $78(28.9)$ & $132(51.2)$ \\
\hline obese (30-39.9) & $29(10.7)$ & $39(15.1)$ \\
\hline \multicolumn{3}{|l|}{ Exercise in daily life } \\
\hline none & $137(50.7)$ & $125(48.4)$ \\
\hline regular & $29(10.7)$ & $19(7.4)$ \\
\hline irregular & $104(38.5)$ & $114(44.2)$ \\
\hline
\end{tabular}


Table 1. Characteristics of respondents in the study aimed at determining the existence of pain in the musculoskeletal system among office workers - cont.

\begin{tabular}{|c|c|c|}
\hline \multirow{2}{*}{ Variable } & \multicolumn{2}{|c|}{$\begin{array}{c}\text { Respondents } \\
(\mathrm{N}=528) \\
{[\mathrm{n}(\%)]}\end{array}$} \\
\hline & $\begin{array}{l}\text { females } \\
(\mathrm{N}=270)\end{array}$ & $\begin{array}{c}\text { males } \\
(\mathrm{N}=258)\end{array}$ \\
\hline \multicolumn{3}{|c|}{ Time spent standing in workplace $(\mathrm{M} \pm \mathrm{SD}=1.88 \pm 1.16)$} \\
\hline $0 \mathrm{~h}$ & $21(7.8)$ & $21(8.1)$ \\
\hline $1-2 \mathrm{~h}$ & $194(71.9)$ & $166(64.3)$ \\
\hline $3-4 \mathrm{~h}$ & $52(19.3)$ & $65(25.2)$ \\
\hline$\geq 5 \mathrm{~h}$ & $3(1.1)$ & $6(2.3)$ \\
\hline \multicolumn{3}{|c|}{$\begin{array}{l}\text { Time spent continuously sitting in workplace } \\
\qquad(\mathrm{M} \pm \mathrm{SD}=4.64 \pm 2.21)\end{array}$} \\
\hline $1-3 \mathrm{~h}$ & $79(29.3)$ & $91(35.3)$ \\
\hline $4-6 \mathrm{~h}$ & $110(40.7)$ & $122(47.3)$ \\
\hline $7-12 \mathrm{~h}$ & $81(30.0)$ & $45(17.4)$ \\
\hline \multicolumn{3}{|l|}{ Breaks taken in workplace } \\
\hline 1 break & $83(30.7)$ & $56(21.7)$ \\
\hline $2-3$ breaks & $118(43.7)$ & $121(46.9)$ \\
\hline$\geq 4$ breaks & $69(25.6)$ & $81(31.4)$ \\
\hline \multicolumn{3}{|l|}{ Exercise in workplace } \\
\hline none & $222(82.2)$ & $193(74.8)$ \\
\hline regular & $6(2.2)$ & $10(3.9)$ \\
\hline irregular & $42(15.6)$ & $55(21.3)$ \\
\hline \multicolumn{3}{|l|}{ Lifting heavy objects in workplace } \\
\hline never & $77(28.5)$ & $81(31.4)$ \\
\hline rarely & $157(58.1)$ & $144(55.8)$ \\
\hline often & $17(6.3)$ & $15(5.8)$ \\
\hline usually & $17(6.3)$ & $16(6.2)$ \\
\hline all the time & $2(0.7)$ & $2(0.8)$ \\
\hline \multicolumn{3}{|l|}{ Experiencing difficulties while working } \\
\hline yes & $192(71.1)$ & $168(65.1)$ \\
\hline no & $78(28.9)$ & $90(34.9)$ \\
\hline \multicolumn{3}{|l|}{ Stress level of work } \\
\hline not stressful & $32(11.9)$ & $38(14.7)$ \\
\hline moderately stressful & $148(54.8)$ & $133(51.6)$ \\
\hline very stressful & $90(33.3)$ & $87(33.7)$ \\
\hline
\end{tabular}


Table 1. Characteristics of respondents in the study aimed at determining the existence of pain in the musculoskeletal system among office workers - cont.

\begin{tabular}{|c|c|c|}
\hline \multirow[t]{2}{*}{ Variable } & \multicolumn{2}{|c|}{$\begin{array}{c}\text { Respondents } \\
(\mathrm{N}=528) \\
{[\mathrm{n}(\%)]}\end{array}$} \\
\hline & $\begin{array}{l}\text { females } \\
(\mathrm{N}=270)\end{array}$ & $\begin{array}{c}\text { males } \\
(\mathrm{N}=258)\end{array}$ \\
\hline \multicolumn{3}{|l|}{ Recurrent hard activity } \\
\hline yes & $73(27.0)$ & $56(21.7)$ \\
\hline no & $197(73.0)$ & $202(78.3)$ \\
\hline \multicolumn{3}{|l|}{ Head position when working at desk } \\
\hline free & $89(33.3)$ & $132(51.2)$ \\
\hline $45^{\circ}$ bent sideways & $85(31.5)$ & $49(19.0)$ \\
\hline leaning forward & $86(31.9)$ & $74(28.7)$ \\
\hline $30^{\circ}$ bent sideways & $10(3.7)$ & $3(1.2)$ \\
\hline \multicolumn{3}{|l|}{ Upper back position when working at desk } \\
\hline straight & $74(27.4)$ & $71(27.5)$ \\
\hline bent & $179(66.3)$ & $168(65.1)$ \\
\hline other & $17(6.3)$ & $19(7.4)$ \\
\hline \multicolumn{3}{|l|}{ Arm position when working at desk } \\
\hline both forearms above the level of the desk & $196(72.6)$ & $175(67.8)$ \\
\hline forearms at the level of the desk & $28(10.4)$ & $21(8.1)$ \\
\hline one forearm above the level of the desk & $46(17.0)$ & $62(24.0)$ \\
\hline \multicolumn{3}{|l|}{ Leg position when working at desk } \\
\hline $\begin{array}{l}\text { straight, with both legs at the same level } \\
\text { one leg over the other }\end{array}$ & $80(29.6)$ & $84(32.6)$ \\
\hline legs bent & $80(29.6)$ & $48(18.6)$ \\
\hline feet parallel to the ground and thighs & $97(35.9)$ & $104(40.3)$ \\
\hline supported & $13(4.8)$ & $22(8.5)$ \\
\hline \multicolumn{3}{|l|}{ Computer position when working at desk } \\
\hline exactly in front & $184(68.1)$ & $204(79.1)$ \\
\hline at $90^{\circ}$ to the side & $8(3.0)$ & $5(1.9)$ \\
\hline at $30^{\circ}$ to the side & $78(28.9)$ & $49(19.0)$ \\
\hline \multicolumn{3}{|l|}{ Position of computer mouse when working at desk } \\
\hline near the keyboard & $243(90.0)$ & $226(87.6)$ \\
\hline distant from the keyboard & $27(10.0)$ & $32(12.4)$ \\
\hline \multicolumn{3}{|l|}{ Type of chair when working at desk } \\
\hline stool & $21(7.8)$ & $9(3.5)$ \\
\hline chair supporting the head, upper and lower back, and arms & $73(27.0)$ & $49(19.0)$ \\
\hline chair supporting the lower back & $53(19.6)$ & $60(23.3)$ \\
\hline chair supporting the lower back and the arms & $123(45.6)$ & $140(54.3)$ \\
\hline
\end{tabular}

M - mean; SD - standard deviation. 
Approximately a half of the female office workers $(45.6 \%)$ and a half of male $(54.3 \%)$ sat on a chair which supported the lower back and the arms when working (Table 1).

The rate of pain complaints among female office workers for lower back $(\mathrm{OR}=0.64,95 \%$ CI: 0.45-0.91), neck $(\mathrm{OR}=0.45,95 \% \mathrm{CI}: 0.32-0.64)$, upper back $(\mathrm{OR}=0.45,95 \% \mathrm{CI}: 0.31-0.63)$, shoulder $(\mathrm{OR}=0.44$, 95\% CI: 0.31-0.64), foot (OR $=0.55,95 \%$ CI: $0.38-0.80)$, $\operatorname{arm}(\mathrm{OR}=0.52,95 \% \mathrm{CI}: 0.35-0.78)$ and wrist $(\mathrm{OR}=0.46$, 95\% CI: $0.30-0.68)$ was significantly higher than in the case of male officer workers $(\mathrm{p}<0.05)$ (Table 2).

It was established that the most frequently experienced pain among the office workers was lower back pain $(55.1 \%)$ and upper back pain $(53 \%)$; lower and upper back and neck pain had mostly been experienced for 12 months or more, and most stated that they had not received treatment.

Analyses of the association between lower back pain and a female office worker revealed that lower back pain was significantly associated with recurrent hard activity in the workplace $(p=0.000)$. In the multiple-regression analyses among female office workers, there was no significant association between other characteristics and lower back pain complaints ( $p>0.05$ ) (Table 3). In the same table, factors such as recurrent hard activity in the workplace, exercise in the workplace, lifting heavy objects in the workplace and the position of a mouse when working at a desk were found to be independently associated with the prevalence of lower back pain among male office workers $(p<0.05)$. In the multiple-regression analyses among male office workers, there was no significant association between other characteristics and lower back pain complaints $(\mathrm{p}>0.05)$ (Table 3).

A multivariate analysis found that neck pain complaints were significantly associated with marital status, time spent continuously sitting in the workplace, the number of breaks taken in the workplace of female office workers $(\mathrm{p}<0.05)$. Neck pain was significantly associated with recurrent hard activity in the workplace of male of-

Table 2. Pain in the musculoskeletal system reported by the office workers

\begin{tabular}{|c|c|c|c|c|c|}
\hline \multirow[t]{2}{*}{ Pain localization } & \multicolumn{2}{|c|}{$\begin{array}{c}\text { Respondents } \\
(\mathrm{N}=528) \\
{[\mathrm{n}(\%)]}\end{array}$} & \multirow[t]{2}{*}{$\mathrm{OR}^{\mathrm{b}}$} & \multirow[t]{2}{*}{$95 \%$ CI } & \multirow[t]{2}{*}{$\mathrm{p}$} \\
\hline & $\begin{array}{c}\text { females }^{\mathrm{a}} \\
(\mathrm{N}=270)\end{array}$ & $\begin{array}{c}\text { males } \\
(\mathrm{N}=258)\end{array}$ & & & \\
\hline Lower back & $163(60.4)$ & $128(49.6)$ & 0.64 & $0.45-0.91$ & $0.013^{*}$ \\
\hline Neck & $167(61.9)$ & $110(42.6)$ & 0.45 & $0.32-0.64$ & $0.000^{*}$ \\
\hline Upper back & $169(62.6)$ & $111(43.0)$ & 0.45 & $0.31-0.63$ & $0.000^{*}$ \\
\hline Shoulder & $135(50.0)$ & $80(31.0)$ & 0.44 & $0.31-0.64$ & $0.000^{*}$ \\
\hline Foot & $123(45.6)$ & $96(37.2)$ & 0.55 & $0.38-0.80$ & $0.002^{*}$ \\
\hline Leg & $107(39.6)$ & $69(26.7)$ & 0.70 & $0.50-1.00$ & 0.052 \\
\hline Arm & $89(33.0)$ & $53(20.5)$ & 0.52 & $0.35-0.78$ & $0.001^{*}$ \\
\hline Wrist & $91(33.7)$ & $49(19.0)$ & 0.46 & $0.30-0.68$ & $0.000^{*}$ \\
\hline
\end{tabular}

OR - odds ratio; $\mathrm{CI}$ - confidence interval.

a The reference group.

${ }^{\mathrm{b}}$ Odds ratios for pain complaints.

$* \mathrm{p}<0.05$. 





fice workers $(p<0.05)$. In the multiple-regression analyses among female and male office workers, there was no significant association between other characteristics and neck pain complaints $(\mathrm{p}>0.05)$ (Table 4).

In the multiple-regression, marital status and recurrent hard activity in the workplace had the positive association with upper back pain complaints of female office workers $(\mathrm{p}<0.05)$. However, arm position at a desk had negative association with upper back pain complains of female ( $\mathrm{p}<0.05)$. In the same table, upper back pain complaints were significantly associated with exercise in the workplace and the head position when working at a desk of male office workers $(\mathrm{p}<0.05)$ (Table 5).

The position of a mouse at a desk and the type of a chair were associated with shoulder pain for female $(\mathrm{p}<0.05)$. Workplace and experiencing difficulties while working were associated with shoulder pain for male $(p<0.05)$. Other predictors were not associated with shoulder pain for both female and male office workers ( $p>0.05$ ) (Table 6). The body mass index (BMI) group, time spent continuously sitting in the workplace and stress level of work had the positive association with leg pain complaints of female office workers $(p<0.05)$. The type of a chair had negative association with leg pain complaints of female $(\mathrm{p}<0.05)$. On the other hand, leg pain complaints were significantly negatively associated with workplace and positively associated with experiencing difficulties while working for male office workers $(p<0.05)$ (Table 7).

Analyses of the association between foot pain and female office worker revealed that foot pain was significantly associated with numerous predictors such as exercise in daily life, working experience, time spent continuously sitting in the workplace, recurrent hard activity in the workplace and arm position when working at a desk for female office workers ( $p<0.05)$. For male workers, age group, lifting heavy objects in the workplace and head position when working at a desk had the negative association with foot pain complaints $(p<0.05)$. In the same table, working experience and recurrent hard activity in the workplace had the negative association with foot pain complaints for male office workers $(\mathrm{p}<0.05)$ (Table 8).

According to the Table 9, only the position of a mouse at a desk was associated with arm pain for male $(\mathrm{p}<0.05)$. Factors related to work were associated with arm pain for female $(\mathrm{p}<0.05)$.

Workplace and arm position when working at a desk were the association with wrist pain complaints for female office workers $(\mathrm{p}<0.05)$. Individual characteristics such as exercise in daily life and BMI group were the association with wrist pain complaints for male office workers $(\mathrm{p}<0.05)($ Table 10).

\section{DISCUSSION}

This cross-sectional descriptive study found a high occurrence of problems with pain of the musculoskeletal system among office workers employed at 9 different institutions in the city of Zonguldak. It is also determined by the International Organization for Standardization (ISO) standards. The ISO 9241 is a multi-part standard covering ergonomics of human-computer interaction. Workstations that meet ISO 9241 Part 5 Workstation layout and postural requirements will generally satisfy this design requirement [17]. The ISO 9241 Part 6 Environmental requirements specify the ergonomics requirements for the visual display terminal working environment that will provide the user with comfortable, safe and productive working conditions. It covers the visual, acoustic and thermal environments [17].

The objective is to provide a working environment that should facilitate efficient operation of the visual display terminal and provide the user with comfortable working conditions. Population data should be used in determining the ergonomic requirements. Anthropometric measurements of population data will vary according to age and gender [17]. The most frequently encountered complaints, varying between 50 and 55\%, were pain in the lower back, upper back 







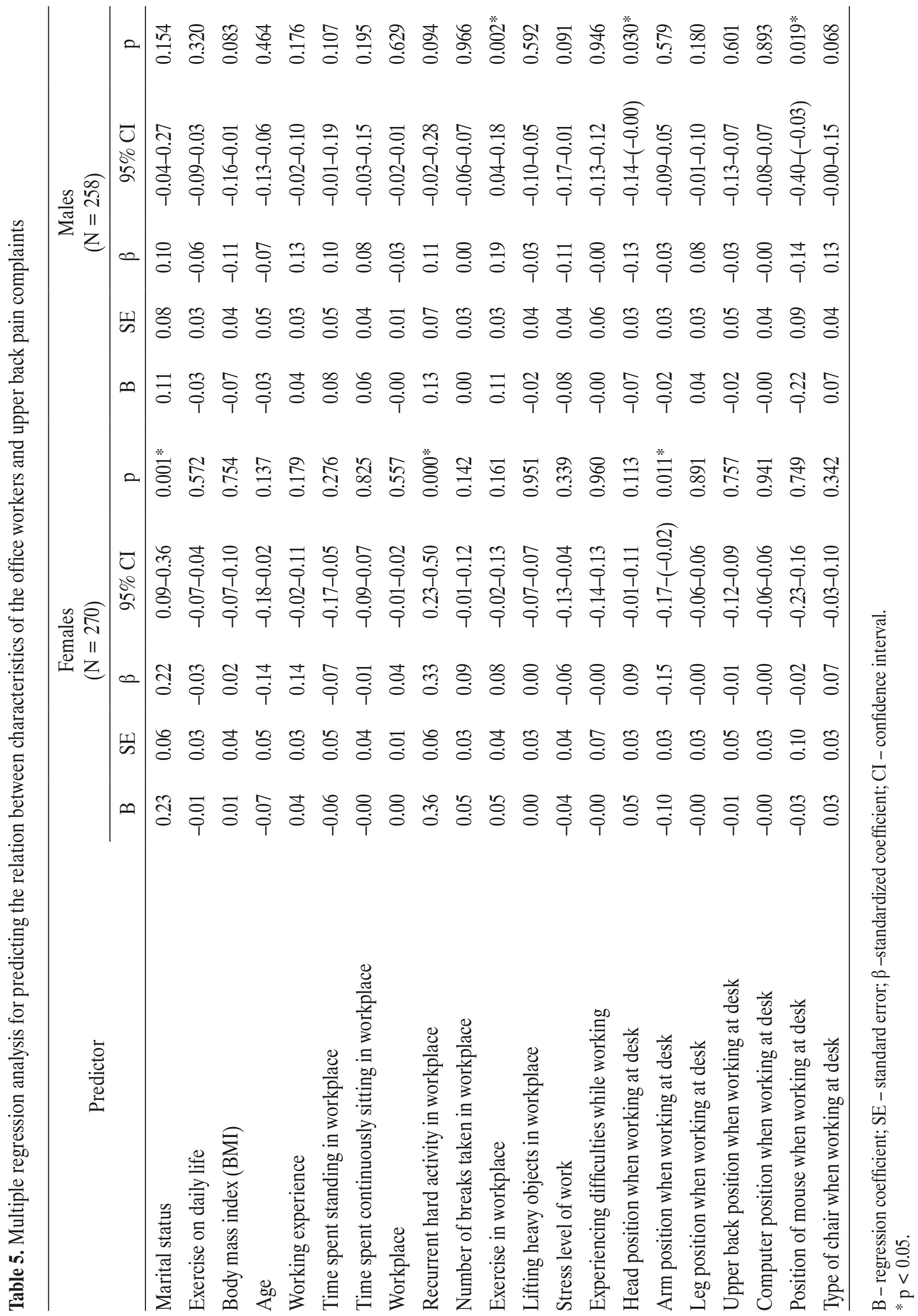




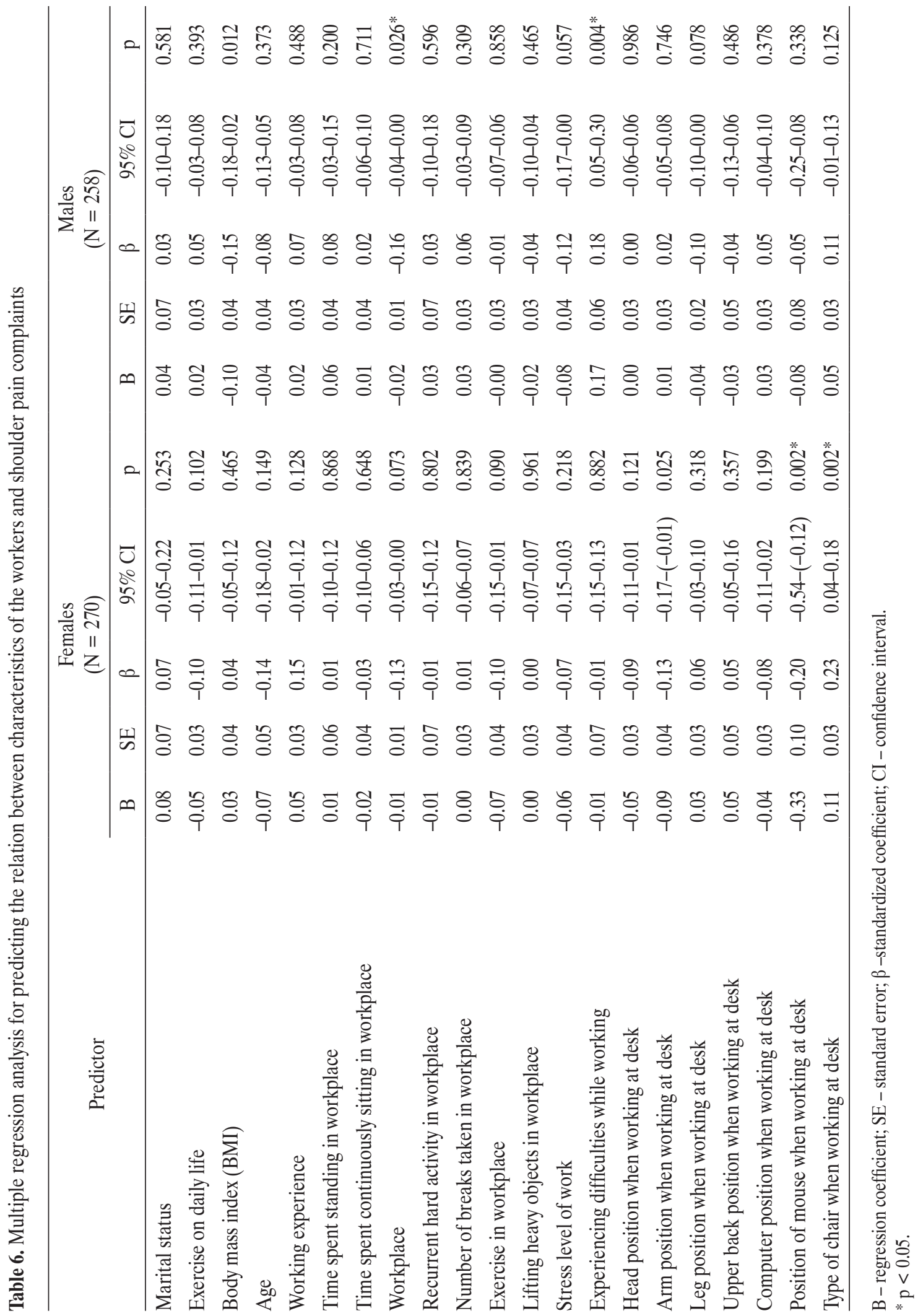




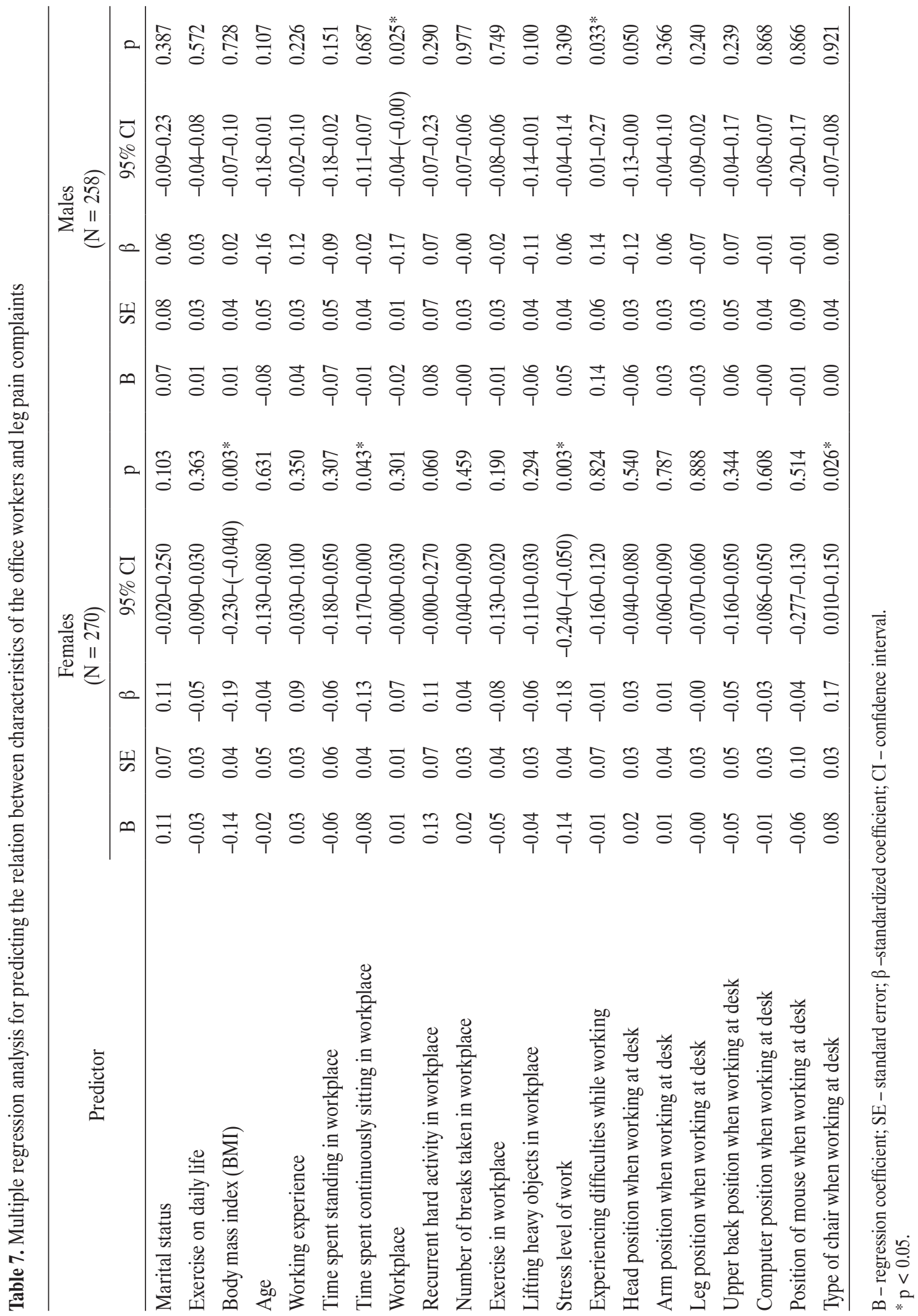









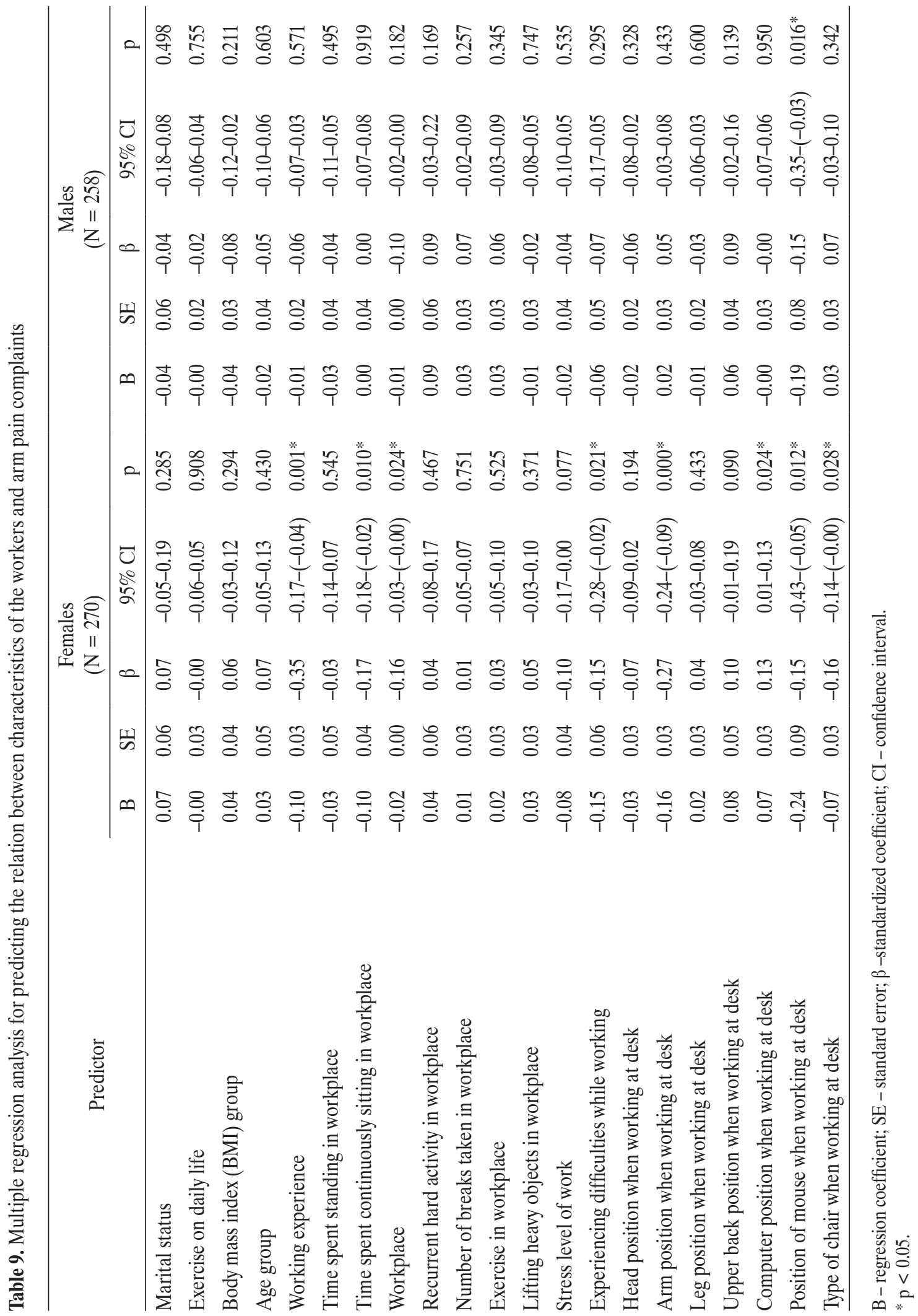




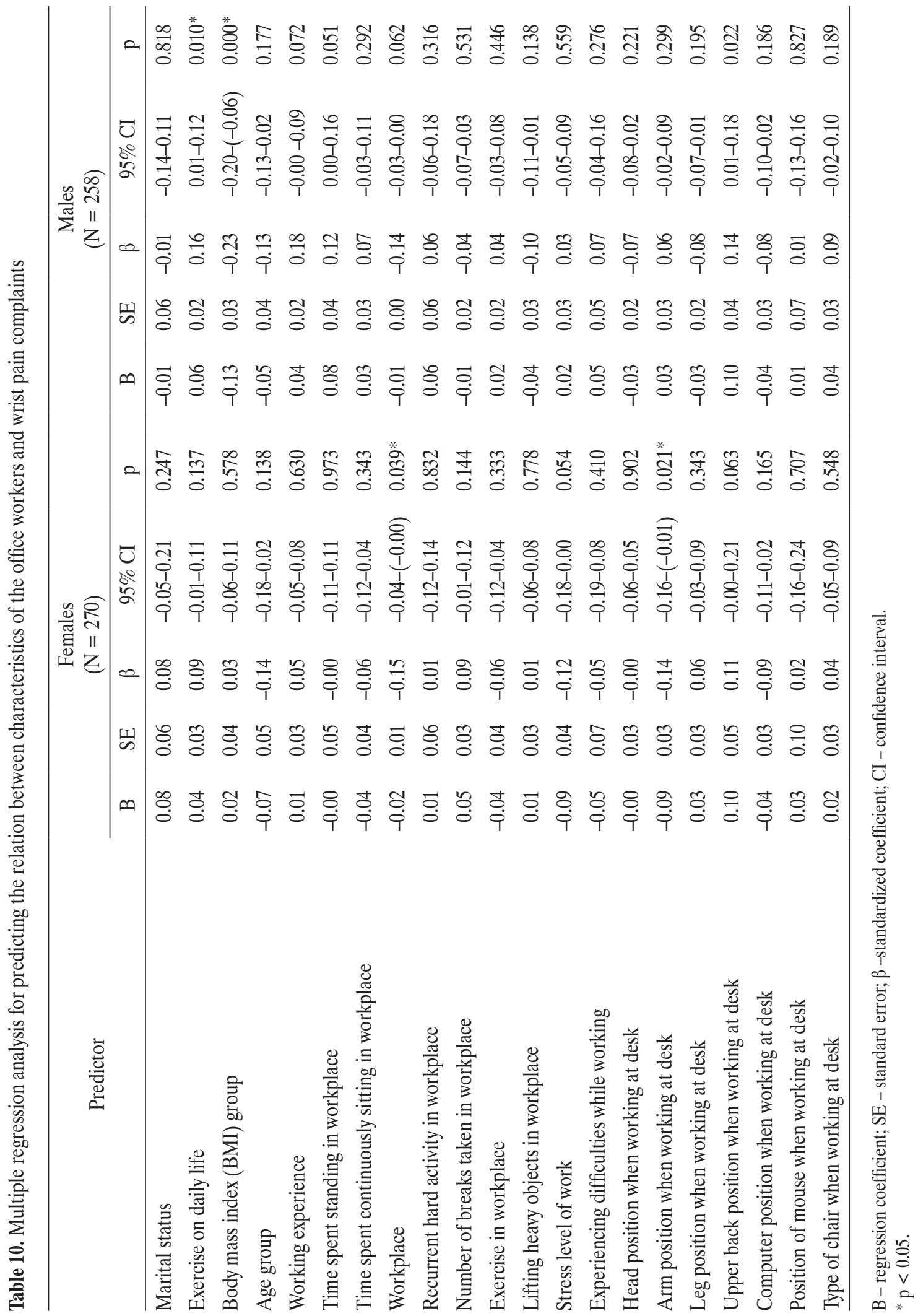


and neck [18]. In industrialized societies, it is reported that the lifetime prevalence of lower back pain is $49-70 \%$, and the point prevalence of lower back pain is $12-30 \%$ [19]. In a study of the Turkish population, Oksuz reported a lifetime prevalence of lower back pain of $44.1 \%$ and a point prevalence of $19.7 \%$ [20]. In a prospective cohort epidemiological study conducted on 5310 workers in Japan, it was shown that notwithstanding those with no previous complaints, work-related lower back pain could develop at a rate of 3.9\% [20].

In addition, it has been stated that the increased use of computers in offices has meant that nearly $70 \%$ of workers suffer musculoskeletal problems in the upper back and neck [21]. It has been established that among women, using a computer and computer mouse for more than $6 \mathrm{~h}$ is correlated with pain in the neck [22]. Pain in the lower back, neck and upper back are more often seen among office workers because they are work-related illnesses [23]. It may be said that the types of disorders of the musculoskeletal system found in this study accord with the findings of previous studies.

Another notable point in this study is that the pain complaints of nearly a half of the workers had continued for 12 months or more, but nearly $80 \%$ of these had not gone for treatment. This may result in a reduction in work performance and have an emotional effect. It has been found in a study on 3311 workers in Spain that work-related MSDs may result in workers leaving work temporarily or permanently [24].

The risk factors for MSDs include ergonomic, psychosocial and individual factors. The relationship of ergonomic and psychosocial factors has been shown. Since ergonomic risk factors may easily be eliminated by a direct approach, they predominate in prevention [25]. In this study, a significant correlation has been found among the variables of age, gender, marital status, taking regular exercise, the number of years working, head, arm leg and the mouse position while working, the type of a chair, time spent continuously sitting and stress level and the experience of pain.
It has been seen in the study that the middle age group experience significant pain in the neck, leg, arm and wrist. The results of a study in which the logistic analysis was performed on 2852 people showed that an increase of one unit in age increased the risk of developing pain by $3.2 \%$ [4]. Extension of the retirement age and the progressive aging of the population mean that individuals continue to work for longer. People now in middle age will in the future form the old age group, and for this reason this significant level of pain should be taken seriously and the necessary measures should be taken.

Scientific research on MSDs has mostly reported that females are more at risk than males independently of the type of work. In a cross-sectional study performed on Swiss computer users, females have reported more symptoms in all parts of their bodies than males, and have suffered more often from harmful physical and psychosocial factors [26]. It has been reported that spending the whole working time doing the same thing has an effect on workrelated musculoskeletal complaints, for example using a computer for more than 2 years constitutes a risk factor for musculoskeletal complaints [27].

When the reasons for problems of the most frequently seen musculoskeletal system among office workers have been examined in this study, it has been found that working with the head inclined at $45^{\circ}$ has a significant effect on lower back, upper back, shoulder and foot pain, while working with both arms above the level of the desk affected pain in the upper and lower extremities and the neck. Ergonomic deficiencies in equipment used, wrong standing and sitting positions and long working hours may cause pain in the musculoskeletal system.

In the literature, it is stated that the correct sitting position is sitting straight and upright in a chair supporting the upper and lower back, and that a large proportion of officerelated lower back pain could be avoided just with the use of lower back support [28]. Shoulders should be relaxed, and the neck should be bent forward or back with the head 
turning no more than $20^{\circ}$. The forearms should be held below or above the level of the desk, bent at $90^{\circ}$ at the elbow, and the forearms should be parallel with the ground and close to the body.

It is known that bending the wrists or keeping them resting on the surface of the desk may cause constriction of nerves in workers. In particular, the computer screen should be positioned so that its upper edge is below eye level, and so that the head does not need to be moved up or down much, and the neck does not need to be bent more than $30^{\circ}$. Also, the knees should be at the same level as or slightly higher than the hips, and the feet should be placed on a slight elevation. In this way pressure on the calves and thighs from the chair will be prevented, so that problems with circulation in the legs will be prevented, as will pain in the legs and feet [27-29].

According to the results of this study, it has been found that having the computer mouse on the desk at a distance from the keyboard has a significant effect on the experience of pain in the upper back, shoulder and arm in office workers. The way of using the computer may cause unnecessary stress in the tendons and nerves of the hands, wrists, and even the shoulders. It has been reported in the literature that the constant repetition of the same movements on the keyboard or the mouse caused by continuously writing or drawing on a computer and the use of force in these movements may result in pain in the arms and hands of office workers and lead to cumulative traumas [30,31]. We are of the opinion that in order to prevent these problems, it is important that workers should periodically rest their hands, perform exercises to stretch their fingers, and keep the keyboard in front of the computer screen.

The characteristics of chairs which office workers use for long periods may cause musculoskeletal problems if they are not ergonomically constructed. A significant difference has been found in this study between the length of time office workers spent continuously sitting in the same position in a chair and the occurrence of pain in the lower back, neck, shoulder, upper back, arm, leg and foot. Simi- larly, sitting in a chair with lower back and arm support has a significant effect on the experience of pain. Remaining in the same position for a long time may put the muscles under stress and reduce the blood flow. This may cause muscular fatigue among workers.

Static muscular activity may result in pain particularly in the hands and shoulders, and reduces performance [30]. It is notable in the literature that ergonomically constructed work chairs which support the head, neck, and upper and lower back significantly reduce the level of musculoskeletal problems. In offices, the five-legged chair is generally to be chosen. The chair height must be adjustable and also the chair should be capable of moving when needed [28]. In a similar way, for jobs where it is necessary to work sitting for long periods, it is emphasized that taking breaks and performing neck, arm and foot exercises on the musculoskeletal system will considerably reduce the rate of these problems [32]. It has been suggested that $10 \%$ of working time taken as rest breaks will not lower productivity [30]. Musculoskeletal problems occur not only in connection with the ergonomic construction of office equipment or the way the workers stand or sit. Along with these factors, others such as marital status, taking regular exercise, anthropometric measurements or bodily abnormalities which are independent of work may have an effect [19]. In new approaches, it is reported that physical, organizational and social factors in the workplace, physical and social aspects of life outside the workplace and personal physical and psychosocial characteristics may play a part in this process [2]. It has been shown that the use of a web camera to develop self-management for the purpose of reducing musculoskeletal disorders has a generally positive effect on male workers, and that along with ergonomic training it achieves an improvement for workers' posture after 6 weeks [33]. Although the body mass index of office workers has not been found to be significantly correlated with the frequency of pain complaints in this study, a significant relationship has been found with being married, not taking exercise in daily 
life, and reporting a moderate or high level of stress in the workplace.

It has been shown in the literature that an ergonomic approach, the provision of a suitable and comfortable work environment and exercise training are effective in correcting posture disorders and musculoskeletal problems and in reducing psychosocial risk factors [34-36]. In the reduction of workplace stress, it is of great importance to carry out appropriate ergonomic changes, to increase organizational support and job satisfaction, to make the workload appropriate in order to reduce pressure of work, and to create opportunities to increase social support in the workplace.

\section{CONCLUSIONS}

From the findings of this study, it has been concluded that among office workers who have been at their desks continuously for long periods, head and arm posture, the position of the computer mouse, the type of a chair used, age, and taking regular exercise in daily life and in the office environment have an effect on the frequently observed problems of pain in the lower back, upper back, shoulder, neck, arm and foot. In the light of these results, it is recommended that:

1. Importance should be attached to providing facilities and activities to help office workers to acquire the habit of physical activity, and to create awareness of ergonomics.

2. Diagnostic systems should be provided for work-related illnesses in Turkey, statistical data should be gathered and laws should be updated.

3. Work should be carried out to help Turkish society acquire the habit of regular physical activity by means of brochures, television programs, etc.

\section{ACKNOWLEDGMENTS}

We would like to thank Uğur Tüfekçi and Mesut Dağınık for their help in gathering data, and the office workers in the institutions where the research was conducted.

\section{REFERENCES}

1. Punnet L, Wegman DH. Work-related muscoleteral disorders: The epidemiologic evidence and debate. J Electromyogr Kinesiol. 2004;14:13-23, https://doi.org/10.1016/j.jele kin.2003.09.015.

2. National Research Council, Institute of Medicine. Musculoskeletal disorders and the workplace: Low back and upper extremities. Washington: National Academy Press; 2001. p. 364-7, https://doi.org/10.17226/10032.

3. Philips SJ, Whisnant JP. Hypertension and stroke. In: Laragh JH, Brenner BM, editors. Hypertension: Pathophysiology, diagnosis, and management. 2nd ed. New York: Reven Press; 1995. p. 465-78.

4. Marcus M, Gerr F, Monteilh C, Ortiz DJ, Gentry E, Cohen S, et al. A prospective study of computer users: II. Postural risk factors for musculoskeletal symptoms and disorders. Am J Ind Med. 2002;41(4):236-49, https://doi.org/10.1002/ajim.10067.

5. Cimbiz A, Uzgören N, Aras Ö, Öztürk S, Elem E, Aksoy CC. [Determination of musculoskeletal pain risk factors using logistic regression analysis: A pilot study]. Turk J Physiother Rehabil. 2007;18(1):20-7. Turkish.

6. Randall R, Griffiths A, Cox T, Welsh C. The activation of mechanisms linking judgements of work design and management with musculoskeletal pain. Ergonomics. 2002; 45(1):13-31, https://doi.org/10.1080/00140130110110593.

7. Melhorn JM, Gardner P. How we prevent prevention of musculoskeletal disorders in the workplace. Clin Orthop Relat Res. 2004;419:285-96, https://doi.org/10.1097/00003086200402000-00045.

8. Amel T, Kumar S. Work-related musculoskeletal disorders: Design as a prevention strategy. A review. J Occup Rehabil. 2001;11(4):255-64, https://doi.org/10.1023/A:1013344508217.

9. Özcan E, Kesiktaş N. [Prevention of occupational musculoskeletal disorders and ergonomics]. Saf Health. 2007;34:6-9. Turkish.

10. Yilmaz F, Şahin F, Kuran B. [Work-related musculoskeletal disorders and treatment]. Nobel Med. 2006;2(3):15-22. Turkish. 
11. Coenen P, Kingma I, Boot CRL, Douwes M, Bongers BM, van Dieën JH. Work-site musculoskeletal pain risk estimates by trained observers - A prospective cohort study. Ergonomics. 2012;55(11):1373-81, https://doi.org/10.1080/00140139. 2012.709540.

12. Atasoy A, Keskin F, Başkesen N, Tekingündüz S. [Occupational musculoskeletal system troubles and assessment of ergonomic risks in laboratory staff]. Perform Qual Health. 2010;1(2):90-113. Turkish.

13. U.S. Department of Labor Occupational Safety and Health Administration. Ergonomics: The study of work [Internet]. Washington: The Department; 2000 [cited 2016 Jan 22]. Available from: https://www.osha.gov/Publications/osha3125.pdf.

14. Crawford JO. The Nordic musculoskeletal questionnaire. Occup Med. 2007;57(4):300-1, https://doi.org/10.1093/occmed/kqm036.

15. Godin G, Shepard R. Godin leisure-time exercise questionnaire. Med Sci Sports Exerc. 1997;29(6):36-8.

16. Kriska AM. Modifiable activity questionnaire. Med Sci Sports Exerc. 1997;29(6):73-8.

17. Stewart T. Ergonomics standards concerning human-system interaction: Visual displays, controls and environmental requirements. Appl Ergon. 1995;26(4):271-4, https://doi. org/10.1016/0003-6870(95)00031-7.

18. Pols MA, Peeters PH, Bueno-De-Mesquita HB, Ocke MC, Wentink CA, Kemper HC, et al. Validity and repeatability of a modified Baecke Questionnaire on physical activity. Int JEpidemiol.1995;24(2):381-8, https://doi.org/10.1093/ije/ 24.2.381.

19. Van Tulder M, Koes B, Bombardier C. Low back pain. Best Pract Res Clin Rheumatol. 2002;16(5):761-75, https://doi. org/10.1053/berh.2002.0267.

20. Oksuz E. Prevalence, risk factors, and preference-based health states of low back pain in a Turkish population. Spine (Phila Pa 1976). 2006;31(25):968-72, https://doi. org/10.1097/01.brs.0000247787.25382.3c.

21. Matsudaira K, Konishi H, Miyoshi K, Isomura T, Takeshita K, Hara N, et al. Potential risk factors for new-onset of back pain disability in Japanese workers: Findings from the Japan epidemiological research of occupation-related back pain study. Spine (Phila Pa 1976). 2012;37:1324-33, https://doi. org/10.1097/BRS.0b013e3182498382.

22. Başakçi Çalik B, Telli Atalay O, Başkan E, Gökçe B. [Analyzing musculoskeletal system discomfort, work interference and risk factors of office workers with computer users]. J Marmara Univ Inst Health Sci. 2013;3(4):208-14, https:// doi.org/10.5455/musbed.20131215111048. Turkish.

23. Johnston V, Souvlis T, Jimmieson NL, Jull G. Associations between individual and workplace risk factors for self-reported neck pain and disability among female office workers. Appl Ergon. 2008;39(2):171-82, https://doi.org/10.1016/ j.apergo.2007.05.011.

24. Eryavuz M, Akkan A. [Assessment of low back pain risk factors in factory employees]. Turk J Phys Med Rehab. 2003;49(5):58-68. Turkish.

25. Abásolo L, Lajas C, León L, Carmona L, Macarrón P, Candelas G, et al. Prognostic factors for long-term work disability due to musculoskeletal disorders. Rheumatol Int. 2012; 32(12):3831-9, https://doi.org/10.1007/s00296-011-2264-5.

26. Türkkan A. [Work-related musculoskeletal diseases and socioeconomic inequality]. Uludağ Med J. 2009;35(2):101-6. Turkish.

27. Karlqvista L, Tornqvista EW, Hagbergb M, Hagmana M, Toomingasa A. Self-reported working conditions of VDU operators and associations with musculoskeletal symptoms: A cross-sectional study focusing on gender differences. Int J Ind Ergon. 2002;30(4-5):277-94, https://doi.org/10.1016/ S0169-8141(02)00131-2.

28. Doğan A, Tekindal B, Baran G, Özgirgin N. [Musculoskeletal disorders and ergonomics among computer users]. Tur J Occup Environ Med. 2011;11(41):45-52. Turkish.

29. Robertson M, Amick BC, DeRango K, Rooney T, Bazzani L, Harrist R, et al. The effects of an office ergonomics training and chair intervention on worker knowledge, behaviour and musculoskeletal risk. Appl Ergon. 2009;40(1): 124-35, https://doi.org/10.1016/j.apergo.2007.12.009. 
30. Yakut H. [A case study ergonomic awarenesses and usage habits on using office equipment of office workers]. Süleyman Demirel Univ J Inst Social Sci. 2013;1:85-96. Turkish.

31. Ulusam S, Kurt M, Dülgeroğlu D. [Cumulative trauma disorders among computer users]. Tur J Occup Environ Med. 2001;2(6):26-32. Turkish.

32. Özcan E, Esmaeilzadeh S, Başat H. [Upper extremity workrelated musculoskeletal disorders among computer users and effectiveness of ergonomic interventions]. Turk J Phys Med Rehab. 2011;57(4):236-41, https://doi.org/10.4274/tftr. 49091. Turkish.

33. Ulucan HF, Zeyrek S. [Occupational health and safety in the office] [Internet]. Ankara: Institute of Occupational Health and Safety Directorate; 2012 [cited 2016 Jan 22]. Available from: http://www.isgum.gov.tr/rsm/file/isgdoc/IG14-ofislerde_ isg.pdf. Turkish.

34. Taieb-Maimon M, Cwikel J, Shapira B, Orenstein I. The effectiveness of a training method using self-modeling webcam photos for reducing musculoskeletal risk among office workers using computers. Appl Ergon. 2012;43(2):376-85, https://doi.org/10.1016/j.apergo.2011.05.015.

35. Levanon Y, Gefen A, Lerman Y, Givon U, Ratzon NZ. Reducing musculoskeletal disorders among computer operators: Comparison between ergonomics interventions at the workplace. Ergonomics. 2012;55(12):1571-85, https:/doi. org/10.1080/00140139.2012.726654.

36. Özcan E, Esmaeilzadeh S, Bölükbaş N. [Work related musculoskeletal disorders and therapy]. Nobel Med. 2007;3(1): 12-7. Turkish.

This work is available in Open Access model and licensed under a Creative Commons Attribution-NonCommercial 3.0 Poland License - http://creativecommons.org/ licenses/by-nc/3.0/pl/deed.en. 